BENTUK PERTUNJUKAN GURITAN PADA TRADISI PERNIKAHAN DI KOTA PAGARALAM

DedyFirduansyah, AbiKaroma Batubara

EKSISTENSI MUSIK KOLINTANG KAYU DALAM KEHIDUPAN PIKPP DI PT.PURSI PALEMBANG SUMATERA SELATAN

RIO EKA PUTRA

ESTETIKA TARI MELAJU DENGAN MUTU

Rully Rochayati, Treny Hera

KAJIAN SOSIOLOGI TARI KEBAGH DI MASYARAKAT DESA PENGANDONANKOTA PAGAR ALAMRANI CHINTIA SARI

KONTRIBUSI GURU SENI BUDAYA DALAM PENGEMBANGAN KREATIFITAS SISWA PADA PEMBELAJARAN SENI TARI

Naomi Diah Budi Setyaningrum

45

PENERAPAN METODE RESITASI DALAM PEMBELAJARAN NOTASI TARI PADA PROGRAM STUDI PENDIDIKAN SENDRATASIK UNIVERSITAS PGRI PALEMBANG

EfitaElvandari

PENGARUH METODE KERJA KELOMPOK PADA HASIL PEMBELAJARAN TARI TOPENG IRENG DI KELAS VIII SMP NEGERI 15 PALEMBANG

NEMI KAROLINA

PENGARUH MUSIK DANGDUTTERHADAP KECERDASAN EMOSI REMAJA SMPKELAS IX

NOVDALY FILLAMENTA

SITI RAFIAH SEBAGAI TOKOH PEREMPUAN PENGEMBAN PERISTIWA DALAM SYAIR ABDUL MULUK KARYA RAJA ALI HAJI

MOHAMMAD ARFANI

STRUKTUR KERUANGAN TARI REJANG RENTENG DALAM UPACARA PERSEMBAHYANGAN DI PURA PUSEH DESA KALIREJO KECAMATAN BELITANG II KABUPATEN OKU TIMUR

IWAYAN AYUNITA 


\title{
EKSISTENSI MUSIK KOLINTANG KAYU DALAM KEHIDUPAN PIKPP DI PT.PURSI PALEMBANG SUMATERA SELATAN
}

\author{
Oleh: \\ Rio Eka Putra \\ (Dosen FKIP Universitas PGRI Palembang Program Studi Pendidikan Sendratasik)
}

\begin{abstract}
ABSTRAK
Perkembangan seni pertunjukan akhir pekan ini Kamis musik tradisional dalam beberapa waktu terakhir berkembang pesat, baik dalam bentuk percampuran tradisi dalam musik modern dan air bersih yang penuh jumlah tradisional.Karena banyaknya sekolah seni yang berpose untuk foto tersebar di seluruh Indonesia. Perkembangan kesenian tradisional mereka muncul dan bergerak dengan aksi lebih cepat dari akulturasi satu wilayah ke wilayah lain, dan mengerang atas segala bentuk hasil karya degradasi manusia di dunia ini tentu saja selalu mengalami perubahan bentuk dan perkembangan dari masa ke masa. ke waktu, sering karena mungkin akan ada pekerjaan yang dilakukan seorang pria adalah hanya seperti itu dan sampai saat itu hanya masalah waktu. Sebagai contoh perkembangan pertunjukan seni musik akhir pekan ini Kamis kayu kolintang (alat musik perkusi melodi) besar di sisi lain berasal dari provinsi sulawesi timur minahasa juga. Saat ini seni musik kayu kolintang (melodi instrumen perkusi) berkembang di wilayah kota Palembang Sumatra Selatan, terutama yang dikendalikan PT.Pusri. Seni ini telah berkembang lebih dari lima tahun, keberadaan seni musik kolintang kayu telah datang karena salah satu berasal dari Sulawesi dan ingin musik berkembang di Palembang Sumatera Selatan. Saat orang-orang seni tertarik untuk mempelajari musik istri dari kayu kolintang sebagian besar karyawan kami PT.Pusri dan telah melakukan banyak pertunjukan kayu seni pertunjukan slide musik dari daerah yang dikendalikan kolintang di atau di luar PT.Pusri Palembang, Sumatra Selatan. Metodologi penelitian yang digunakan adalah metode deskriptif kualitatif. Subjek penelitian adalah ketua kelompok yang disebut mother teresa pikpp (ibu persatuan karyawan PT.Pusri Palembang). Obyek dalam penelitian ini setelah peneliti melakukan serangkaian observasi, teknik pengumpulan tanggal yang digunakan adalah teknik observasi, wawancara dan dokumentasi.Perkembangan yang cukup pesat maka peneliti ingin menulis keberadaan dan pengembangan musik kayu kolintang di masyarakat Sumsel khususnya di PT Pursi Palembang Sumsel.
\end{abstract}

Kata kunci: keberadaan, seni musik kayu kolintang.

melodinya menggunakan bahasa dan

\section{A. PENDAHULUAN}

Musik daerah atau musik tradisional adalah musik yang lahir dan berkembang

di daerah- daerah di seluruh Indonesia.Ciri khas pada jenis musik ini teletak pada isi lagu dan instrumen (alat musiknya). Musik tradisi memiliki karakteristik khas, yakni syair dan gaya daerah setempat, dari sekian banyaknya pulau beserta dengan masyarakatnya tersebut lahir, tumbuh dan berkembang. Seni tradisi merupakan identitas, jati diri, dan media ekspresi dari masyarakat pendukungnya.Hampir di seluruh wilayah Indonesia mempunyai seni musik tradisional yang 
khas.Keunikan tersebut bisa dilihat dari teknik permainannya, penyajiannya, maupun bentuk/organologi instrumen musiknya.Hampir seluruh seni tradisional Indonesia mempunyai semangat kolektivitas yang tinggi sehingga dapat dikenali karakter khas orang/masyarakat Indonesia, yaitu ramah dan sopan.Namun berhubung dengan perjalanan waktu dan semakin berkembangnya sebuah kesenian tersebut, karakterpun berubah atau beralkuturasi sesuai dengan daerah tempat berkembangnya sebuah kesenian, maka untuk lebih mudah mengenalinya dapat digolongkan menjadi beberapa kelompok yaitu alat musik/instrumen perkusi melodi, petik, dan gesek.

Kesenian tradisional Kolintang kayu, adalah kesenian yang tumbuh dan berkembang di wilayah PT.Pusri Palembang Sumatera Selatan, dan merupakan bentuk kesenian yang tumbuh dan berkembang di kalangan istri dari karyawan PT.Pusri. Perbedaan dengan Kolintang kayu yang ada di Minahasa dan daerah lain di Indonesia walaupun dalam penyebutannya sama yaitu Kulintang. Seperti halnya kesenian tradisional yang lain, kesenian tradisional Kolintang kayu ini juga merupakan kesenian asli yang berasal dari Minahasa.
Perkembangan kesenian tradisional Kolintang kayu di PT.Pusri sangat baik, dikarenakan para istri karyawan PT.Pusri yang membentuk organisasi yang bernama PIKPP (Persatuan Ibu-ibu karyawan PT. PUSRI Palembang). Kegiatan pengembangan diri di PT. Pusri Palembang memiliki peranan penting dalam melestarikan Budaya yang ada di Nusantara ini khususnya dalam rangka acara resmi di dalam wilayah PT. Pusri.

PIKPP kelompok seni adalah sebuah kumpulan yang terdiri dari ibu-ibu istri karyawan PT. Pusri Palembang, dimana tujuannya dalam pembangunan masyarakat yang tumbuh dari bawah yang pengelolaannya dari, oleh, dan untuk masyarakat menuju terwujudnya keluarga yang beriman dan bertaqwa kepada Tuhan Yang Maha Esa, berakhlak mulia dan berbudi luhur, sejahtera, maju dan mandiri, kesetaraan dan keadilan gender (Jenis kelamin) serta kesadaran hukum dan lingkungan seperti yang dilakukan oleh beberapa anggota kumpulan ibu-ibu PIKPPyang ada di PT. Pusri Palembang. Kumpulan ibu-ibu PIKPP yang ada di PT. Pusri Palembang memiliki tujuan dan sasaran dalam pengelolaan pemberdayaan kesejahteraan keluarga khusus dalam ruang keluarga besar PT. Pusri 
Palembang. (wawancara ibu Teresa, ketua grup, 10 Agustus 2018).

Melihat eksistensi dari Kesenian tradisional Kolintang kayu setelah melakukan observasi dikarenakan peneliti adalah guru yang mengajar Kesenian tradisional Kolintang kayu di PT.Pusri.peneliti melihat perkembangan yang cukup pesat, dimulai dari lagu-lagu yang dimainkan tidak hanya lagu tradisi,

\section{B. METODE PENELITIAN}

Metode penelitian pada dasarnya merupakan cara ilmiah untuk mendapatkan data dengan tujuan dan kegunaan tertentu. Jenis penelitian ini adalah penelitian deskriptif kualitatif. Metode penelitian kualitatif sering disebut metode penelitian naturalistik karena penelitiannya dilakukan pada kondisi yang alamiah (natural setting); disebut juga sebagai metode etnographi, karena pada awalnya metode ini lebih banyak digunakan untuk penelitian bidang antropologi budaya; disebut sebagai metode kualitatif, karena data yang terkumpul dan analisisnya lebih bersifat kualitatif (Sugiyono : 2011:54).

Dalam penelitian ini menggunakan jenis metode deskriptif kualitatif.Metode deskriptif adalah peneliti mengumpulkan melainkan memainkan lagu-lagu yang populer saat sekarang ini.

Dari penjabaran di atas hal yang melatar belakangi Peneliti untuk Menulis mengenai "Eksistensi Musik Kolintang kayu Dalam Kehidupan PIKPP DI PT.Pursi Palembang Sumatera Selatan yaitu: Perkembangan diri, masyarakat dan kesenian Kolintang kayu ditengahtengah masyarakat sekitar PT.Pusri Palembang Sumatera Selatan.

data dan mencatat keadaan atau fenomena yang terkait langsung atau tidak langsung dengan fokus penelitian. Penelitian kualitatif adalah penelitan yang bermaksud untuk memahami fenomena tentang apa yang dialami oleh subjek penelitian misalnya perilaku, persepsi, motivasi, tindakan dan lain-lain, secara holistik dan dengan cara deskripsi dalam bentuk kata-kata dan bahasa, pada suatu konteks khusus yang alamiah dan dengan memanfaatkan berbagai metode ilmiah (Moleong : 2012).

Sesuai dengan pokok permasalahan yang dikaji penelitian ini menggunakan pendekatan kualitatif, yaitu pendekatan dengan cara melihat objek pengkajian sebagai suatu sistem, dengan kata lain objek kajian dilihat sebagai satuan yang terdiri dari unsur yang saling terkait. 
Penelitian kualitatif lebih mengutamakan kualitas data.Oleh karena itu, teknik pengumpulan datanya banyak menggunakan wawancara yang berkesinambungan dan observasi langsung. Penelitian yang dilakukan bersifat kualitatif, artinya penelitian yang menghasilkan data deskriptif analisis yang berupa kata-kata tertulis terhadap apa yang diamati, atau dengan kata lain data yang dianalisis dan hasil analisisnya berbentuk deskriptif.

\section{PEMBAHASAN}

\section{Teknik Observasi}

Penelitian ini dilaksanakan selama satu bulan, mulai tanggal 2 Januari sampai dengan tanggal 16 Maret 2017. Pertemuan pertama dilaksanakan pada hari Jumat pukul 14.00 WIB di Gedung Kesenian PT.Pusri

Palembang.Pertemuan pertama ini peneliti melakukan observasi dan berkonsultasi dengan pimpinan grup Kolintang kayu yaitu Ibu Teresa tentang maksud dan tujuan serta jadwal penelitian.

TABEL 1

LEMBAR OBSERVASI GRUP Kolintang kayu PT.Pusri

\begin{tabular}{|c|c|c|}
\hline NO & Jadwal & $\begin{array}{c}\text { TeknikPengumpulan } \\
\text { Data }\end{array}$ \\
\hline
\end{tabular}

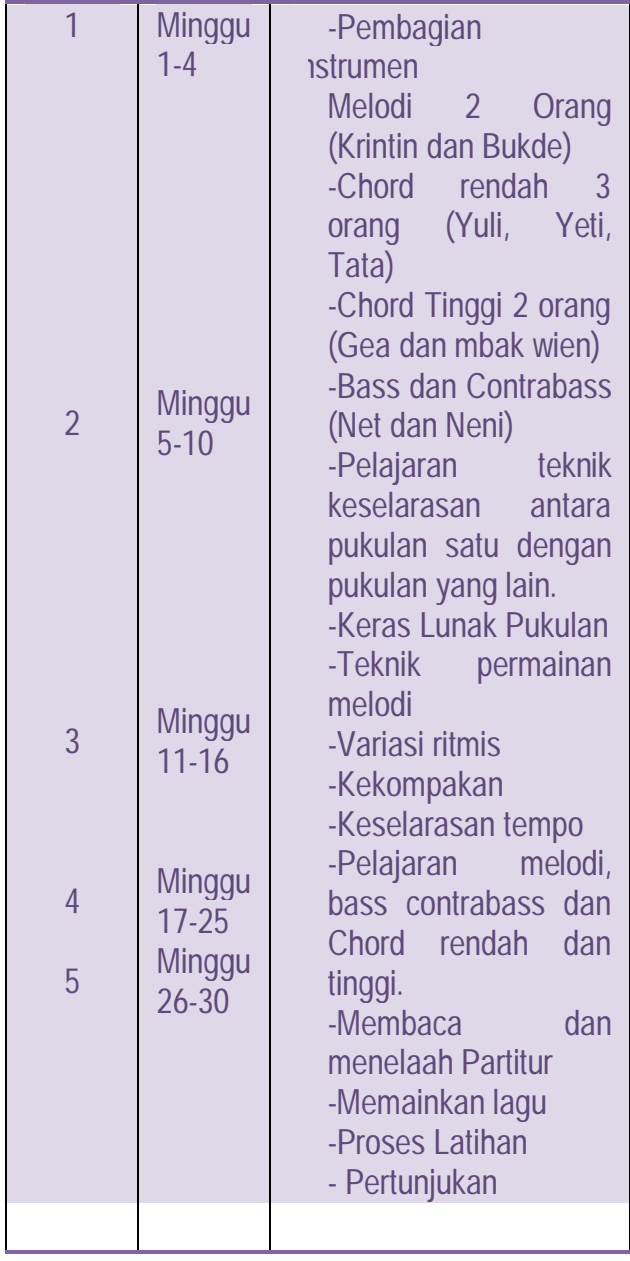

Pertemuan kedua, dilaksanakan pada hari Jumat, 17 Januari 2017 pukul 14.00 17.00 WIB di gedung kesenian PT.Pusri. Pada pertemuan kedua, peneliti melakukan wawancara kepada pimpinan grup yaitu Ibu Teresa mengenai hal-hal yang terkait di dalam penelitian ini seperti, instrumen dan pemain, Perkembangan lagu yang dimainkan, dan bagaimana bentuk pertunjukan yang akan diselenggarakan.

Teknik observasi peneliti dan bahan yang pelajaran dalam Kolintang kayu terdiri dari 
beberapa instrumen yang berbeda dan klarifikasinya:

2. Pengumpulan data, Sebelum masuk ke dalam jenis instrumen kolintang, ada beberapa Chord yang harus diketahui para pemain kolintang kayu:

1. $C=1-3-5$

2. $D=2-4-6$

3. $E=5 \#-7-3$

4. $F=4-6-1$

5. $G=5-7-2$

6. $A=6-1 \#-3$

7. $B=7-2 \#-4$

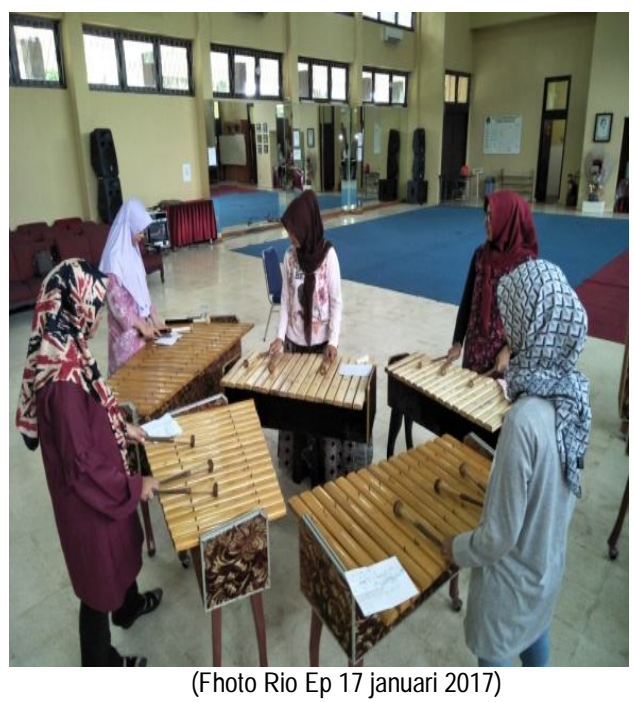

Teknik memainkan Chord dalam kolintang satu stik tangan kanan dan dua stik tangan kiri.

(Fhoto Rio Ep 17 januari 2017)

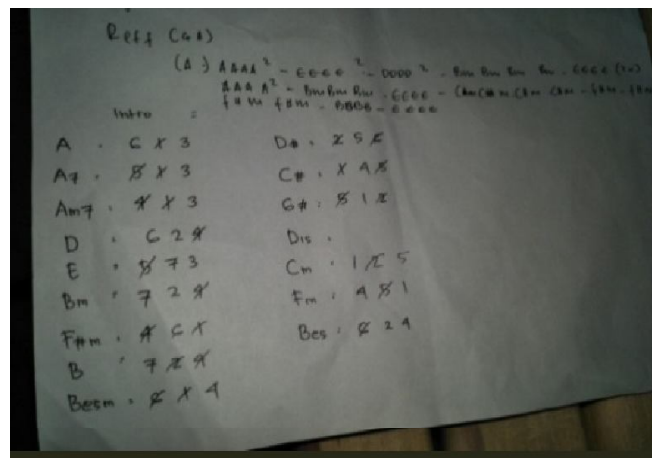

Klarifikasi musik kolintangkayu PT.Pusri Palembang Sumatera Selatan

\section{a) Kolintang Melodi}

Kolintang melodi, Pemain kolintang melodi terdiri dari dua orang, melodi satu memainkan melodi inti lagu, melodi dua memainkan harmoni lagu. Pada kolintang melodi ini terdiri dari 4 oktaf dari C1 rendah ke C4 lebih tinggi.Teknik permainan lebih memainkan melodi dengan memakai 2 stik pendek, melodi yang dihasilkan lebih keras karena memakai 2 nada yang harmonis.

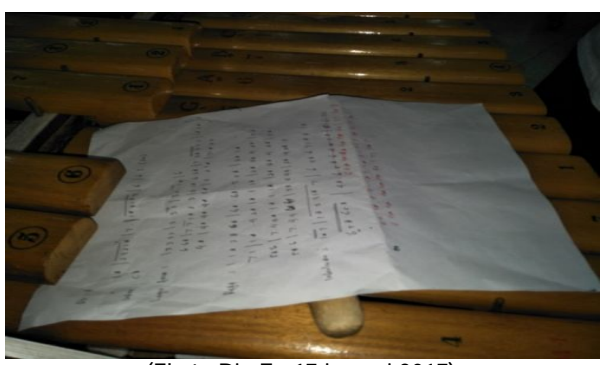

(Fhoto Rio Ep 17 januari 2017)

Selanjutnya teknik baca partitur pada kolintang melodi sebagai berikut:

Sesuai dengan pengalaman dari pemain teknik baca partitur menggunakan not angka dan not balok agar lebih memudahkan ibu-ibu dalam membaca melodi yang akan dimainkan.

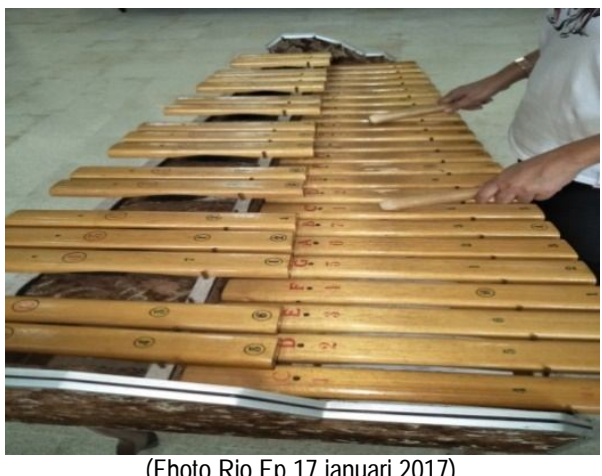

Nada-nada pada kolintang melodi: 


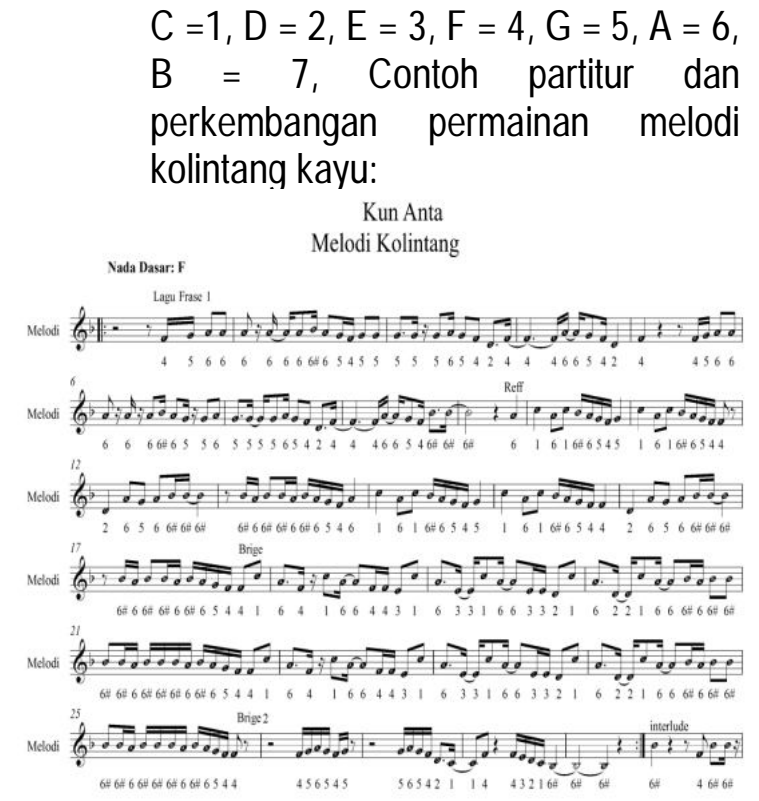

\section{A. Kolintang Chord Rendah}

Pada Kolintang Chord ini memilki 3 oktaf pemukul dari alat ini ada tiga buah, satu ditangan kiri, dua ditangan kanan. Teknik permainannya pemukul serempak (sama) ketiga stick yang dimainkan. Wilayah nada dari Chordd rendah dimulai C2 sampai $\mathrm{C} 4$, Chord rendah sifatnya sebagai alas dari Chord lagu yang dimainkan.

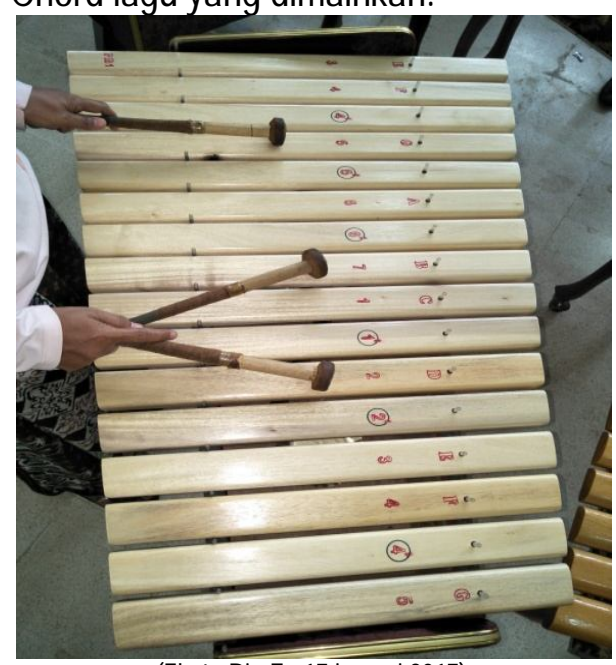

(Fhoto Rio Ep 17 januari 2017)

Selanjutnya teknik baca partitur pada kolintang Chord rendah sebagai berikut:

Huruf $F($ besar $)=$ tanda pukulan kuat
Huruf $f($ kecil $)=$ tanda pukulan sedang

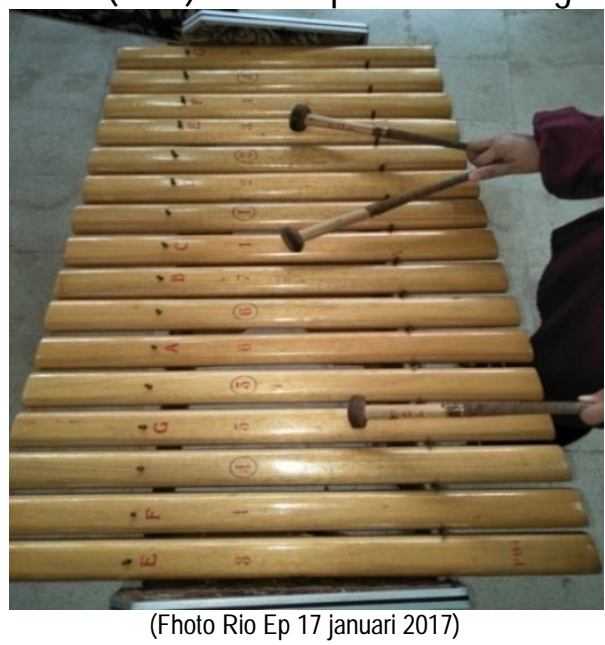

Contoh baca partitur pada lagu kolintang kayu:

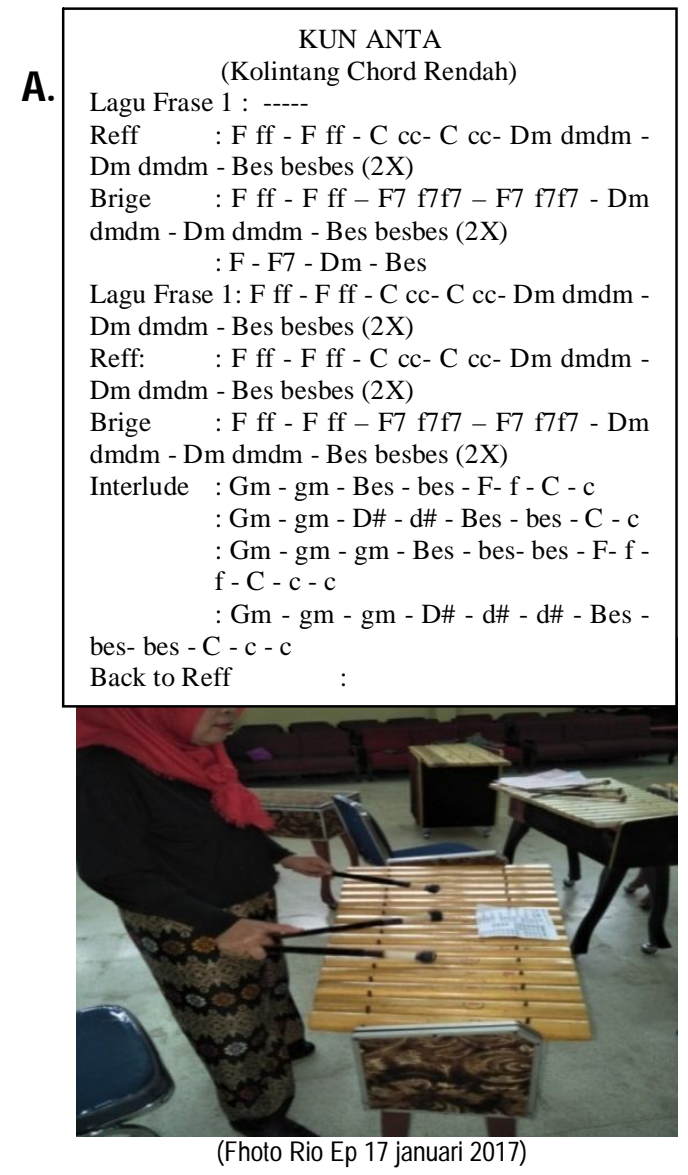

Selanjutnya teknik baca partitur pada kolintang Chord tinggi sebagai berikut: Huruf $F$ (besar) = tanda pukulan kuat, Huruf $\mathrm{f}($ kecil $)$ = tanda pukulan sedang 
Sama halnya dengan chord rendah, perbedaan dari chord rendah adalah dari segi pukulan yang lebih variasi atau meningkah

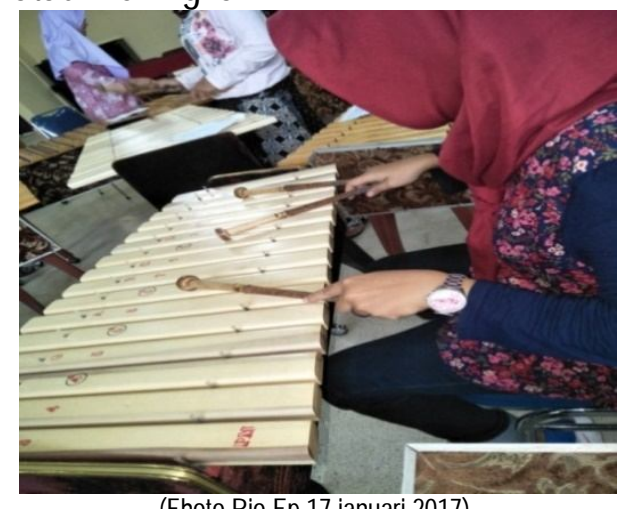

(Fhoto Rio Ep 17 januari 2017)

Contoh baca partitur pada lagu kolintang kayu

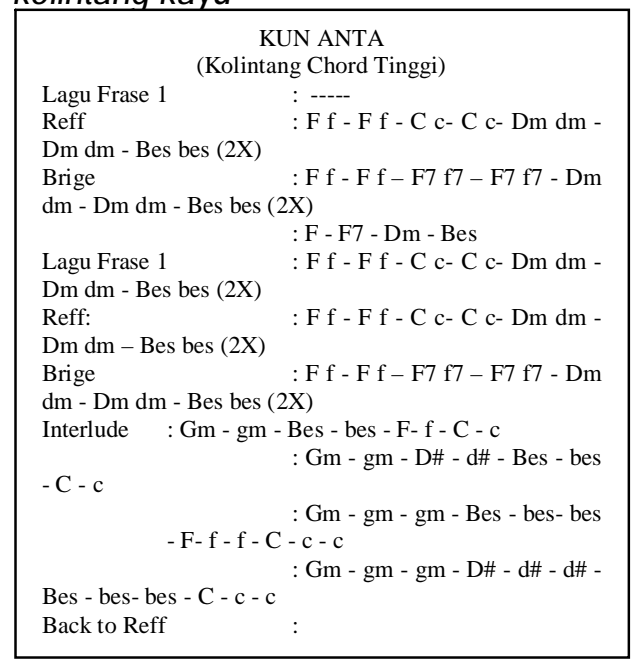

\section{B. Kolintang Bass dan Contrabass}

Kolintang Bass dan Contrabass lebih besar dari intrumen lainnya, karena sifat sebagai alas dari melodi dan Chord, fungsi dari bass dan contrabass sangat penting jika tampa bass dalam permainan kolintang kayu maka permainan melodi dan Chord menjadi kurang bagus atau terasa kosong. Wilayah nada bass dan contrabass terdiri dari 3 oktaf rendah dimulai dari C1 sampai C3.

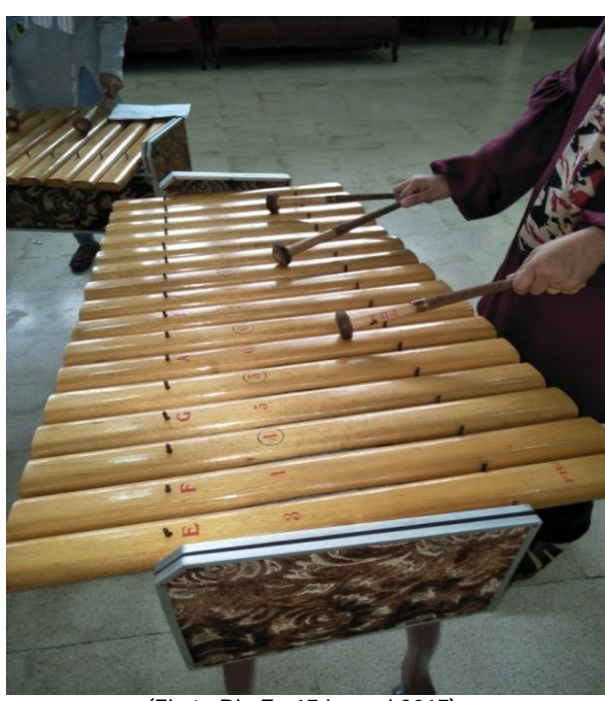

(Fhoto Rio Ep 17 januari 2017)

Selanjutnya teknik baca partitur pada kolintang Bass dan Contrabass sebagai berikut:

Angka $4616=$ Chord F, teknik pukul satu persatu dimulai dari angka 4-6-16 dan seterusnya Bass dan Contrabass adalah backgrond dari permainan kolintang kayu teknik permainan dari bass dan contrabass adalah dengan teknik pukul sejajar dan bergantian antara tangan kanan dan kiri.

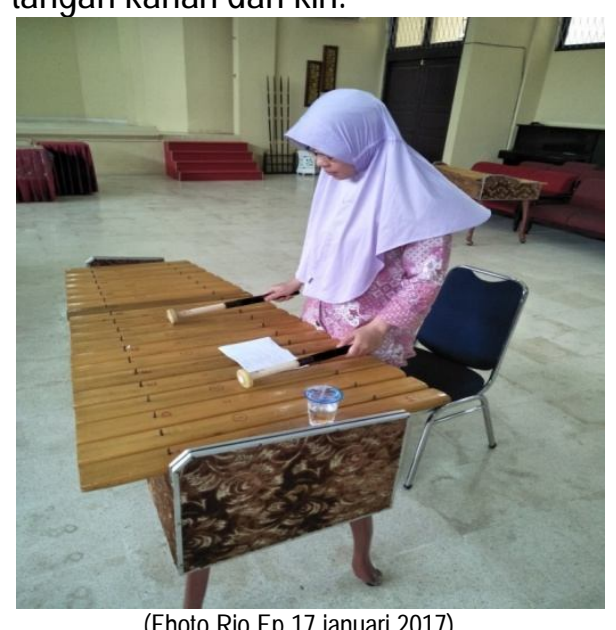

Contoh partitur dari bass dan contrabass sebagai berikut: 


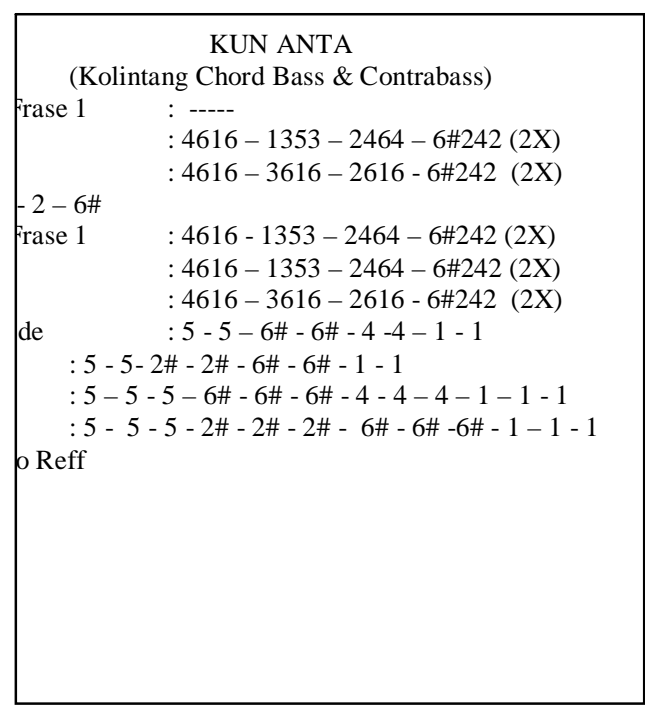

Selanjutnya pertemuan ketiga dilaksanakan pada hari Jumat, 16 maret 2017 pukul 09 - 11.00 WIB di gedung kesenian PT.Pusri Palembang. Pada pertemuan ketiga ini, peneliti langsung ke lokasi pertunjukan yang pada saat itu berada di gedung GPS yang berada dalam PT.Pusri. Pada pertemuan ketiga ini peneliti juga mendokumentasikan seluruh pertunjukan dari awal persiapan hingga akhir pertunjukan selesai, dokumentasi berupa data tertulis serta foto-foto dan video dari awal hingga akhir pertunjukan.

Persentase perkembangan dari ibu-ibu PIKPP DI PT.Pursi Palembang Sumatera Selatan dalam pertunjukan yang diadakan di GPS gedung pertemuan PT.Pusri Palembang Sumatera Selatan. https://www.youtube.com/watch?v=a66sNipSLUY

\section{https://www.youtube.com/watch?v=e1Elklc-Z04}

\section{Teknik Wawancara}

Wawancara adalah percakapan dengan maksud tertentu. Percakapan dilakukan oleh dua pihak yaitu pewawancara (interviewer) yang mengajukan pertanyaan dan pihak yang diwawancarai (interviwee) yang memberikan jawaban atas pertanyaan tersebut Moleong : 2012).

Wawancara harus dilakukan dengan efektif, artinya dalam waktu yang sesingkat-singkatnya dapat diperoleh data sebanyak-banyaknya. Bahasa harus jelas, terarah, suasana harus tetap rileks agar data yang diperoleh data yang obyektif dan dapat dipercaya (Arikunto : 2010:271).

Dalam teknik wawancara yang digunakan dalam penelitian ini adalah interview bebas terpimpin yaitu pewawancara membawa pedoman yang merupakan garis besar tentang hal yang akan diteliti. Pertanyaan itu secara khusus ditujukan kepada informan penelitian, yakni ketua Grup kolintang kayu PT.Pusri Palembang.

Adapun langkah-langkah yang digunakan dalam teknik wawancara adalah :

a. Menentukan informan yang akan dijadikan sebagi sumber informasi.

b. Menentukan waktu wawancara. 
c. Membuat daftar pertanyaan wawancara, yang memuat hal-hal yang perlu ditanyakan kepada sumber/ informan.

Dalam memilih informan yang dianggap menguasai dan dapat di percaya untuk menjadi sumber data yang jelas, informan yang dipilih adalah Grup kolintang kayu PT.Pusri Palembang Sumatera Selatan

TABEL 2

WAWANCARA KEPADA RUSNAWI (KETUA GRUP KULINTANG)

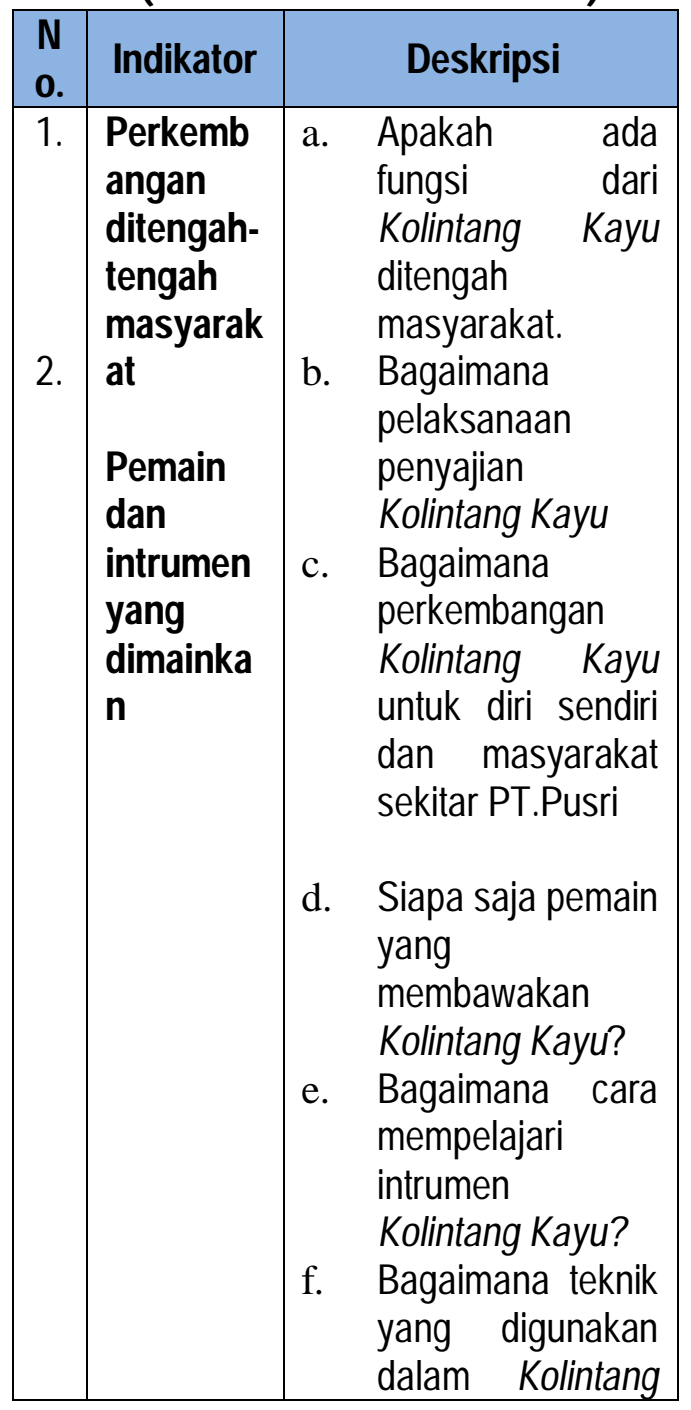

\begin{tabular}{|l|l|}
\hline & \multicolumn{2}{|l|}{ Kayu } \\
g. & Bagaimana aturan \\
& dan ketentuan \\
& dalam memukul \\
alat musik & Kulintang dalam \\
& arak-arakan \\
& pengantin? \\
\hline
\end{tabular}

\section{KESIMPULAN}

Berdasarkan hasil penulisan dan pengamatan dilapangan terkait dengan Eksistensi musik kolintang kayu dalam kehidupan PIKPP di PT.Pusri Palembang Sumatera Selatan, Peneliti menyimpulkan bahwa eksistensi musik kolintang tersebut sampai saat ini mengalami banyak perkembangan dimulai dari teknik permainan, lagu yang dimainkan serta perkembangan ditengah-tengah masyarakat.Perkembangan tersebut dapat dilihat dari segi pertunjukan yang diselenggarakan serta keinginan masyarakat untuk ikut berperan aktif dalam melestarikan kesenian musik kolintang kayu di PT.Pusri Palembang Sumatera Selatan.

Metode penelitian yang digunakan adalah metode deskriptif kualitatif. Subjek penelitian adalah Ketua Grup yang bernama Ibu Teresa PIKPP (Persatuan Ibu-ibu karyawan PT. PUSRI Palembang). Objek dalam penelitian ini setelah peneliti melakukan serangkaian observasi, Teknik pengumpulan data yang digunakan adalah teknik observasi, 
wawancara dan dokumentasi.Melihat perkembangan-perkembangan yang cukup pesat oleh karena itu peneliti ingin menulis eksistensi dan perkembangan musik Kolintang kayu dalam kehidupan masyarakat Sumatera selatan khususnya di PT Pursi Palembang Sumatera Selatan.

Melihat eksistensi musik kolintang kayu di daerah kota Palembang banyak mengalami perkembangan, dalam pemilihan materi yang dimainkan serta teknik-teknik aransemen kebaharuan. Faktor penghambat dalam eksistensi adalah beberapa dari pemain memiliki usia lanjut, dan peserta belum mengerti irama, peserta belum tertanam feeling atau rasa musikal, anggota yang tidak tetap dan konflik internal antara masingmasing peserta.

\section{DAFTAR PUSTAKA}

Arikunto, Suharsimi. 2010. Prosedur Penelitian Suatu Pendekatan Praktek. Jakarta: Rineka Cipta.

Moleong, J. Lexy. 2002. Metodologi Penelitian Kualitatif. Bandung: PT. Remaja Rosdakarya.

Sugiyono. 2011. Metode Penelitian Kuantitatif, Kualitatif dan R\&D. Bandung: Alfabeta. 
